\title{
Reflections and Exploration of Internet Entrepreneurship Educational Modes for University Students
}

\author{
Ying ZHANG ${ }^{1, a}$ \\ ${ }^{1}$ Department of Teaching Affairs, Jilin Agricultural University, 130118, Changchun, China \\ aemail:jlauzy@126.com
}

Keywords: colleges and universities; college students; mobile Internet; entrepreneurship education; startup service

\begin{abstract}
The mobile Internet is both a new source of growth for employment and starting a business and a new perspective and space for college students' entrepreneurship education. The development of the internet provides a practical platform for the business education of the applied undergraduate colleges. Developing education courses about internet business will perfect our country' s entrepreneurship education mode in applied undergraduate colleges. Colleges and universities should design network entrepreneurship courses, optimize the teaching of network entrepreneurship education, optimize the curriculum system and build platforms for entrepreneurship education to promote college students' mobile- Internet- based entrepreneurship education to further development.
\end{abstract}

\section{Introduction}

Notice of the State Council on Doing a Good Job in Employment of Graduates of Nationwide General Institutes of Higher Education 2013 stipulates, "Various regions and departments shall actively improve entrepreneurship policies, enhance entrepreneurship education, training and services, vigorously support entrepreneurship of university graduates, and encourage them to start enterprises especially featuring technology, comprehensive utilization of resources and knowledge intensification and enjoying development priority in the local and national level.” The Ministry of Education has also issued Opinions on Vigorously Promoting Innovational Entrepreneurship Education and Entrepreneurship of Graduates in Institutes of Higher Education, requiring various universities to improve their innovational entrepreneurship education as well as entrepreneurship guidance services to realize breakthroughs of driving employment with entrepreneurship.

\section{Influence of the Internet on entrepreneurship education in institutions of higher education}

Progress and dilemmas of entrepreneurship education in institutions of higher education

A series of policies and documents related to entrepreneurship innovation issued by Report of the 18th National Congress of the Communist Party of China and governments of all levels have shown that entrepreneurship education for university students has gained increasing attention. Through vertical comparison, it can be seen entrepreneurship education for university students has achieved sustainable development. However, there is still a great gap between China and developed countries like the US and European countries. Research findings also revealed that many institutions of higher education copied some already-proved methods and modified them slightly for further promotion in their campus. As a result, entrepreneurship education has still been in a chaotic status lacking logic. A complete curriculum system has not yet taken shake. Problems such as lack of professional entrepreneurship teachers, backward curriculum and textbook development and inadequate entrepreneurship practices have not yet been solved. Education content related to the mobile Internet has not yet been efficiently integrated. Inadequate attention is paid to improvement of entrepreneurship education in the mobile Internet environment.

New opportunities brought by the Internet for entrepreneurship education for institutions of higher education 
Along with development of China's 4G construction, the Internet is embracing accelerated development and the Internet applications are becoming more mature, thus promoting continuous expansion of informationalized services of production, office work, mobile e-commerce, mobile traffic flow and smart household management, and breeding many new business forms and service patterns. With innovational thinking as the selling point and relying on simple and mature software techniques, Internet entrepreneurship, Internet entrepreneurship holds great attraction to university students with rich knowledge but lacking resources. The mobile hardware price is plummeting, and the popularity of intelligent devices is increasing. These have created favorable conditions for institutions of higher education to purchase relevant devices and carry out the mobile Internet entrepreneurship education. Internet-related fields have been greatly favored by investor, thus providing favorable external environment and capital support for large-scale entrepreneurship education in institutions of higher education and implementation of entrepreneurship programs.

\section{Selection of entrepreneurship modes for university students in the "Internet+" era}

\section{E-commerce entrepreneurship mode}

As a product of the Internet era, e-commerce is receiving increasing recognition in the public. First, university students can open online stores on some e-commerce platforms. Based on market surveys and their own career planning, they can choose products to be sold in their online stores. During the process, they can keep on developing their store characteristics and brand images. Second, university students can develop and build new online shopping platforms to keep on attracting investors to start their business there. Development of online shopping platforms is to provide transaction platforms for users, on which users can open their own stores. Entrepreneurs can make profits by collecting rents and advertising fees from stores on their platforms.

Technology entrepreneurship mode

Technology entrepreneurship mode is for university students proficient in applications of computer and network techniques. Some specialized websites and webpages can be designed and made, or university students can consider planning and operating websites of their own or make use of search engine optimization to increase visits and target users for some websites so that users can save a large number of fees for increasing search volume. Besides, university entrepreneurs can make profits by adding advertising services for commodities and services on websites operated by them.

Entrepreneurship mode featuring "Internet+transformation of traditional industries"

The traditional industries can be combined with the Internet to increase the former's operational abilities. University students can also create business platforms for traditional industries based on website construction and data programming techniques, thus changing marketing modes and advertising modes of traditional industries, seeking a foothold for traditional enterprises on the Internet platform and increasing reputation and customer resources for them.

Micro-entrepreneurship mode

The arrival of the Internet era has boosted development of the mobile Internet. An increasing number of mobile APPs have been developed. With a mobile phone, a person can stay at home all day long. Micro-Shop, a new-type online business system developed based on WeChat, allows buyers and sellers check product information and interaction on the WeChat platform. University entrepreneurs can enhance their advertising through some proper methods, expand their potential customer group and keep on learning lessons and accumulating experiences to head towards a more ambitious goal.

\section{Teaching practices for Internet entrepreneurship education}

Internet entrepreneurship curriculum design

Internet entrepreneurship education is different from the traditional entrepreneurship education curriculum. Internet entrepreneurship education has not only similarity of general entrepreneurship education, but also characteristics of the Internet entrepreneurship education. The purpose of 
Internet entrepreneurship education is to integrate entrepreneurship qualities into entrepreneurship education, encourage innovation and improve students' innovational abilities, qualities, knowledge and techniques.

Knowledge system optimization of the Internet entrepreneurship curriculum

Universities should extensively carry out entrepreneurship education, innovate the talent cultivation mechanism and build a complete innovational entrepreneurship education curriculum system. According to the talent cultivation positioning, efforts should be made to promote organic integration of professional education and innovational entrepreneurship education, enhance construction of general education, broaden students' horizon and develop their comprehensive abilities. Besides, universities should enhance university students' entrepreneurship practices to invigorate their innovational spirit and strengthen their innovational ability training. Cultivation of the innovation-driven entrepreneurship abilities can promote all-around development of students. The Internet entrepreneurship curriculum system should set up curriculum systems according to practical situations in local applied colleges and universities to combine theoretical knowledge and Internet entrepreneurship practices.

Teaching strategies for Internet entrepreneurship education

Internet is a highly practical subject, so Internet entrepreneurship education is a practice-oriented education dominated by teachers. In class, students should encourage to participate in discussing, thinking and operating. The implementation of the Internet entrepreneurship education curriculum system calls for comprehensive participation of students. In every class, students should fully participate in it and summarize what has been acquired after class. Through the curriculum system, teachers teach students the entrepreneurship spirit and thinking. Details in the entrepreneurship process should be experienced by students during the future professional learning process. Apart from the Internet entrepreneurship abilities, Internet entrepreneurship education also develops students' entrepreneurship spirit and innovational abilities. The latter is more important. Besides, it should be noted that entrepreneurship education should not be restricted to development of students' entrepreneurship abilities. Entrepreneurship education in essence should contribute to shaping of all-around entrepreneurship qualities of students.

Establishment of the entrepreneurship practice platform in four dimensions

First, knowledge reserve dimension. Extend entrepreneurship education to the scientific research lab, and select tutors for different research teams so as to provide more targeted guidance, improve students' professional abilities and lay a solid foundation for entrepreneurship and innovation. Second, auxiliary learning dimension. Purposely design some programs through summer and winter vocation social practices, guide students to deeply observe social and economic activities, conduct an in-depth observation and investigation of the mobile Internet enterprises and enhance university students' perceptual and rational cognition. Third, outward development dimension. Student associations in universities play a positive role in improving university students' entrepreneurship abilities, professional knowledge, basic skills, occupational spirit and psychological qualities. Fully dig the value of student associations as a warm-up for university students' entrepreneurship, select entrepreneurship tutors, simulate "social enterprise operation," hold activities revolving around entrepreneurship, share and stimulate entrepreneurship innovation, consolidate innovational achievements, develop and reserve talents for enterprises. Fourth, application and practice dimension. Hold entrepreneurship competitions and other comprehensive training and launch practice platforms relying on various entrepreneurship design contests and by cooperating with mobile Internet enterprises to familiarize university students with the whole entrepreneurship process, enhance their understanding of theoretical knowledge, and help them targetedly adjust their knowledge structure, optimize entrepreneurship skills and select ta proper entrepreneurship path.

\section{Conclusion}

Internet entrepreneurship is an indispensable part of entrepreneurship education for university students in China, and an important development trend of entrepreneurship education modes. As a new driving force of the Internet, university students is a main force of entrepreneurship. Applied 
undergraduate colleges and universities should fully recognize advantages of internet entrepreneurship education. combine their characteristics with local economic characteristics, carry out Internet entrepreneurship education in campus, transform their entrepreneurship concepts and teaching methods, and develop a galaxy of Internet entrepreneurship talents with innovational ability and up to requirements of the era.

\section{References}

[1] Zheng Xiaoyi. On the Mobile-Internet-based Entrepreneurship Education in Colleges and Universities[J]. Journal of Shenyang agricultural university,2015(7).

[2] Meng Bo. Discussion on Carrying out Internet Entrepreneurship Education in Undergraducate Colleges[J]. Journal of Changsha aeronautical vocational and techninal and technical college,2011(12).

[3] $\mathrm{Hu}$ Xin. Study on college students entrepreneurship Internet plus mode[J]. Information Technology and Informatization,2015(11).

[4] Ke Limin. The dilemma of College Students' Network Entrepreneurship and the training of competence [J]. Journal of Innovation and Enterprise Education,2012(4).

[5] Hong Tianfeng.Research on College Students' entrepreneurial mode under the Internet thinking[J]. Oriental Enterprise Culture,2016(8). 